\title{
Cystatin and Glomerular Filtration Rate in Obese Versus Non-obese Adolescents
}

\author{
Azza Abd El-Shaheed ${ }^{1}$, Nermine N. Mahfouz ${ }^{1}$, Reham F. Fahmy ${ }^{1}$, Mona A. Elabd ${ }^{1 * \mathbb{D}}$, Hiba Sibaii ${ }^{2}$, Salwa Refat El-Zayat ${ }^{2}$, \\ Mahitab I. El-Kassaby², Hagar H. Mourad² \\ ${ }^{1}$ Department of Child Health, National Research Centre, Medical Research Centre of Excellence, Cairo, Egypt; ${ }^{2}$ Department of \\ Medical Physiology, Medical Research Division, Medical Research Centre of Excellence, Cairo, Egypt
}

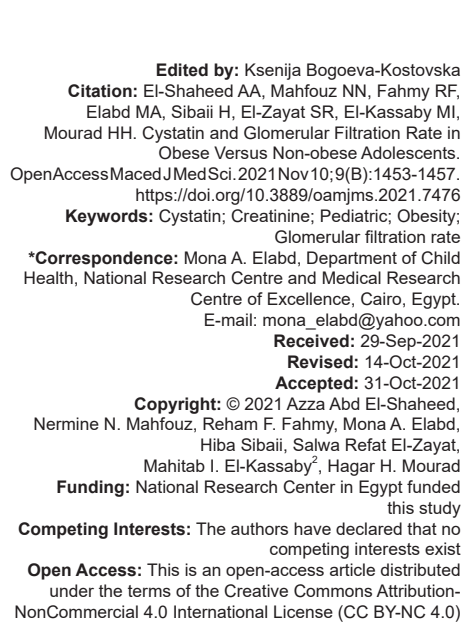

\section{Abstract}

BACKGROUND: Obesity is well known as an independent risk factor for chronic kidney disease thus meticulous assessment of renal function is more essential in obese individuals. Glomerular filtration rate (GFR) is commonly estimated based on serum creatinine $(\mathrm{Cr})$. However, using $\mathrm{Cr}$ as marker of kidney function has some limitations and cystatin $\mathrm{C}$ (CystC) has been reported as an alternative marker

AIM: This study was designed to assess renal function using both GFR and cystatin in obese adolescents.

METHODS: This case-control study enrolled ninety Egyptian adolescents aged between 10 and 18-years-old who were divided equally into two groups according to body mass index (obese and non-obese). Each participant was subjected to full medical history taking, anthropometric measures, and laboratory investigation including Complete blood count, serum Cr, estimated GFR, and CystC

RESULTS: Serum Cr level was significantly higher in obese adolescents compared to non-obese mean values of 0.94 and 0.79 , respectively, with $p=0.007$. Also, eGFR based on $\mathrm{Cr}$ was significantly lower in the obese group compared to controls 73.1 and 85.30 , respectively with $p=0.048$. CystC showed non-significant higher levels in obese group versus controls with mean value of 2.28 and 1.85 , respectively with $p=0.928$. CystC at cut-off value of 1.525 and $95 \% \mathrm{Cl}$ showed a sensitivity of $47.2 \%$ and specificity of $63.9 \%$ for evaluation of kidney affection in obese children and adolescences.

CONCLUSION: GFR is affected in obese adolescence with elevation of serum $\mathrm{Cr}$ and unexpected non-significant elevation of CystC in obese adolescence when compared by the control group.

\section{Introduction}

Childhood obesity became an epidemic problem in both developed and developing countries. It is known to have a significant impact on both physical and psychological health [1]. Furthermore, an emergent interest in the link between obesity and renal injury has been existed. A high body mass index (BMI) is strongly related to new-onset chronic kidney disease (CKD) since a compensatory hyperfiltration occurs according to the higher metabolic demand of the increased body weight (WT). This augmented intraglomerular pressure may enhance kidney damage and, in the long term, raise the risk for CKD. Obesity is also suggested to be a risk factor for nephrolithiasis, and kidney cancer [2]. The renal effect of pediatric obesity has not been adequately investigated besides the incomplete consensus on the various parameters of renal function [3].

In early kidney injury, serum creatinine (Cr) does not increase until moderate reduction in GFR occurs [4].
Cystatin C (CystC) is a 122-amino acid basic protein that synthesized by nucleated cells and freely filtered through the glomeruli. It is reabsorbed and totally metabolized in kidney tubular cells without excretion, so it can be an alternate marker for GFR [4].

Moreover, serum CystC is not affected by age, gender, race, and muscle mass and also does not have a lag period for rising in early kidney injury [5], [6].

Thus this study was conducted to assess renal function in obese Egyptian adolescents using GFR, Cr, and cystatin and try to find the best method for detecting early kidney affection.

\section{Subjects and Methods}

This case-control study was conducted at the Medical Research Centre of Excellence in the clinic of immune-nutrition, in the National Research Centre. 
Ninety Egyptian adolescents who aged between 10 and 18-years-old were selected on purpose of BMI in this study and divided into two groups according to BMI. Obese group included forty-five children with $\mathrm{BMI} \geq 85^{\text {th }}$ centile while the control group enrolled forty-five matched peers with $\mathrm{BMI}<85^{\text {th }}$ centile. Children with syndromic and endocrinal causes of obesity were excluded from this study. Approval of the study protocol was obtained by the Ethical Committee of the Egyptian National Research Centre No 16130. Before the study, each participant's legal guardian signed a written informed consent form in accordance with the World Medical Association's code of ethics (Helsinki Declaration) [7].

\section{Each participant was subjected to}

1. Full medical history taking including family history of obesity and other health problems.

2. Anthropometric measures including height (HT) that determined to the nearest $0.5 \mathrm{~cm}$ on a Holtain portable anthropometer (University of London Institute of Child Health), and WT which measured to the nearest $0.1 \mathrm{~kg}$ on a Seca scale Balance (Model 767 1321004), made in Germany with the child dressed in minimal clothing and no shoes. BMI was also calculated as WT $(\mathrm{kg}) / \mathrm{HT}\left(\mathrm{m}^{2}\right)$. Data were then plotted on the WHO curves using the software AnthroCalc v1.66 Homeon WHO curves [8].

3. Laboratory investigation including complete blood count, serum $\mathrm{Cr}$, estimated GFR $($ eGFR $)=0.413^{*}(\mathrm{HT} /$ Standardized Serum $\mathrm{Cr})$ and cystatin. Human CystC ELISA Kit Cayman chemical, USA was used for the quantitative determination of serum CystC concentration that is produced by Sino Gene Clon Biotech Co., Ltd, catalog No. SG 10555.

\section{Statistical analysis}

Data analysis was performed using Statistical Package for the Social Science (SPSS) version 21 (SSPS Inc, Pennsylvania, USA). Continuous data were expressed as mean $\pm S D$, non-parametric data presented as median and range while categorical data were expressed as frequencies and percentages. Categorical variables were compared using Chi square analysis while continuous non-parametric variables were compared by the Mann-Whitney test. Independent t-test was used also for the comparison between two groups with quantitative parametric data. $p$-value was considered statistically significant at $p<0.05$. The sensitivity and specificity of cystatin for the detection of kidney affection in obese children were assessed by the receiver operating characteristic (ROC) curve.

\section{Results}

The current study enrolled two groups of obese and non-obese children who aged $13.05 \pm 2.61$ and $12.62 \pm 2.60$ respectively with non-significant difference between both groups ( $p=0.446)$. Female sex was more predominant in both groups $(71.1 \%$ in obese, $60 \%$ in non-obese) with non-significant difference ( $p=0.267)$ (Table 1).

Table 1: Demographic and anthropometric data of the studied groups

\begin{tabular}{|c|c|c|c|c|c|}
\hline Parameters & BMI Centile & Min. & Max. & Mean \pm SD & $p$ value \\
\hline \multirow[t]{2}{*}{$\mathrm{Age}^{\mathrm{a}}$} & Obese & 9.00 & 18.00 & $13.05 \pm 2.61$ & 0.446 \\
\hline & Non-Obese & 8.00 & 17.00 & $12.62 \pm 2.60$ & \\
\hline \multirow[t]{2}{*}{ Sex* } & Male & $13(28.9 \%)$ & $18(40 \%)$ & $1.230^{*}$ & 0.267 \\
\hline & Female & $32(71.1 \%)$ & $27(60 \%)$ & & \\
\hline \multirow[t]{2}{*}{$W T^{a}(\mathrm{~kg})$} & Obese & 38.50 & 128.50 & $73.41 \pm 18.26$ & 0.001 \\
\hline & Non-Obese & 18.00 & 66.00 & $37.39 \pm 10.68$ & \\
\hline \multirow[t]{2}{*}{ WT SD ${ }^{b}$} & Obese & 0.96 & 3.00 & $2.18 \pm 0.69$ & 0.001 \\
\hline & Non-Obese & -4.06 & 0.86 & $-1.01 \pm 1.21$ & \\
\hline \multirow[t]{2}{*}{ WT Centile } & Obese & 83.00 & 99.90 & $96.26 \pm 4.80$ & 0.001 \\
\hline & Non-Obese & 0.10 & 80.80 & $27.43 \pm 25.05$ & \\
\hline \multirow[t]{2}{*}{$\mathrm{HT}^{\mathrm{a}}(\mathrm{cm})$} & Obese & 131.50 & 175.00 & $154.16 \pm 10.65$ & 0.002 \\
\hline & Non-Obese & 114.50 & 171.50 & $146.05 \pm 13.04$ & \\
\hline \multirow[t]{2}{*}{ HT SD ${ }^{b}$} & Obese & -2.54 & 2.32 & $0.26 \pm 1.07$ & 0.001 \\
\hline & Non-Obese & -3.93 & 1.19 & $-0.83 \pm 1.23$ & \\
\hline \multirow[t]{2}{*}{ HT Centile ${ }^{\mathrm{b}}$} & Obese & 0.60 & 98.20 & $51.50 \pm 28.89$ & 0.003 \\
\hline & Non-Obese & 0.10 & 88.00 & $32.60 \pm 28.74$ & \\
\hline \multirow[t]{2}{*}{$\mathrm{BMI}^{\mathrm{a}}$} & Obese & 20.00 & 42.90 & $30.55 \pm 5.61$ & 0.001 \\
\hline & Non-Obese & 12.20 & 25.10 & $17.22 \pm 2.71$ & \\
\hline \multirow[t]{2}{*}{ BMI SD ${ }^{b}$} & Obese & 1.25 & 3.00 & $2.47 \pm 0.57$ & 0.001 \\
\hline & Non-Obese & -3.00 & 0.94 & $-0.72 \pm 1.15$ & \\
\hline \multirow[t]{2}{*}{ BMI Centile $^{b}$} & Obese & 89.60 & 99.90 & $98.30 \pm 2.68$ & 0.001 \\
\hline & Non-Obese & 0.10 & 82.90 & $34.40 \pm 28.16$ & \\
\hline
\end{tabular}

${ }^{a}$ Comparison between the groups using independent samples t-test at sig. level 0.05 (Parametric data), ${ }^{b}$ Comparison between the groups using Mann-Whitney test at sig. level 0.05 (Non-Parametric data), ${ }^{*}$ Chi-Square. WT: Weight, HT: Height, BMI: Body mass index

Regarding BMI of both groups, its mean was $30.55 \pm 5.61$ in the obese group and $17.22 \pm 2.71$ in the non-obese group with a significant $P$ value of 0.001 . There was also significant difference between both groups regarding, WT, WT standard deviation, WT centile, BMI $S D$, and BMI centile $(p=0.001)$. Furthermore, there were significant differences between both groups regarding HT, HT SD, HT centile ( $P=0.002,0.001$, and 0.003, respectively) (Table 1$)$. Cystatin levels in obese group showed insignificant higher values $(2.28 \pm 2.55)$ compared to non-obese group $(1.85 \pm 0.64)$ with $p=0.928$ (Table 1).

Concerning laboratory findings, there was not significant difference between the two groups regarding hemoglobin, platelet count, and white blood cell count ( $p=0.629,0.432,0.625$, respectively) (Table 2 ).

Table 2: Laboratory data of the studied groups

\begin{tabular}{|c|c|c|c|}
\hline Parameters & BMI Centile & Mean \pm SD & $p$ value \\
\hline \multirow[t]{2}{*}{$\operatorname{Hemoglobin}^{a}(\mathrm{~g} / \mathrm{dl})$} & Obese & $13.04 \pm 1.19$ & 0.629 \\
\hline & Non-Obese & $12.92 \pm 1.06$ & \\
\hline \multirow[t]{2}{*}{ Platelet count ${ }^{\mathrm{a}}$ (thousands/cmm) } & Obese & $285.87 \pm 62.35$ & 0.432 \\
\hline & Non-Obese & $275.95 \pm 55.96$ & \\
\hline \multirow[t]{2}{*}{ White blood cell (thousands/cmm) } & Obese & $7.08 \pm 2.04$ & 0.625 \\
\hline & Non-Obese & $6.88 \pm 1.82$ & \\
\hline \multirow[t]{2}{*}{ Cystatin $^{b}$ (mg/L) } & Obese & $2.28 \pm 2.55$ & 0.928 \\
\hline & Non-Obese & $1.85 \pm 0.64$ & \\
\hline \multirow[t]{2}{*}{ Creatinine $^{\mathrm{a}}(\mathrm{mg} / \mathrm{dl})$} & Obese & $0.94 \pm 0.23$ & 0.007 \\
\hline & Non-Obese & $0.79 \pm 0.21$ & \\
\hline \multirow[t]{2}{*}{ GFR $^{b}$} & obese & $73.10 \pm 22.33$ & 0.048 \\
\hline & Non-Obese & $85.30 \pm 32.25$ & \\
\hline
\end{tabular}

Regarding Cr levels, it was significantly higher in obese children $(0.94 \pm 0.23)$ compared to non-obese 
$(0.79 \pm 0.21)$ with $p=0.007$, (Table 2$)$. The eGFR using $\mathrm{Cr}$ level was also significantly lower in obese children $(73.10 \pm 22.33)$ compared to non-obese (85.30 \pm 32.25$)$ with $p=0.048$ (Table 2).

Table 3: Medical history of the studied groups

\begin{tabular}{|c|c|c|c|c|c|}
\hline \multirow[t]{2}{*}{ Parameters } & \multirow[t]{2}{*}{ Groups } & \multicolumn{2}{|c|}{ BMI centile } & \multirow[t]{2}{*}{ Chi-square } & \multirow[t]{2}{*}{$p$ value } \\
\hline & & $\begin{array}{l}\text { Obese } \\
\mathrm{N}(\%)\end{array}$ & $\begin{array}{l}\text { Non-Obese } \\
\mathrm{N}(\%)\end{array}$ & & \\
\hline Obese Family Member & $\begin{array}{l}\text { Yes } \\
\text { No }\end{array}$ & $\begin{array}{l}36(81.8) \\
8(18.2)\end{array}$ & $\begin{array}{l}26 \text { (59.1) } \\
18(40.9)\end{array}$ & 5.459 & 0.019 \\
\hline Renal Disease of a Family Member & $\begin{array}{l}\text { Yes } \\
\text { No }\end{array}$ & $\begin{array}{l}13(29.5) \\
31(70.5)\end{array}$ & $\begin{array}{l}10(22.7) \\
34(77.3)\end{array}$ & 0.530 & 0.467 \\
\hline Diabetes Mellitus in the Family & $\begin{array}{l}\text { Yes } \\
\text { No }\end{array}$ & $\begin{array}{l}31(70.5) \\
13(295)\end{array}$ & 31 (70.5) & 0.001 & 1.000 \\
\hline Hypertension in the Family & $\begin{array}{l}\text { Yes } \\
\text { No }\end{array}$ & $\begin{array}{l}18(40.9) \\
26(59.1)\end{array}$ & $\begin{array}{l}25(56.8) \\
19(43.2)\end{array}$ & 2.228 & 0.135 \\
\hline Dyslipidemia in the Family & Yes & $4(9.1)$ & $6(13.6)$ & 0.451 & 0.502 \\
\hline
\end{tabular}

When it comes to family history, $36(81.8 \%)$ of obese group had an obese family member compared to $26(59.1 \%)$ of the non-obese group with a significant difference $(p=0.019)$. However, there was no significant difference between both groups regarding other parameters of family history including renal disease, diabetes mellitus, hypertension, and dyslipidemia ( $p=0.467,1.000,0.135$, and 0.502 , respectively) (Table 3 ) ROC curve at $95 \% \mathrm{Cl}$ of cystatin for the detection of kidney affection in obese children showed sensitivity of $47.2 \%$ and specificity of $63.9 \%$ (Table 4 and Figure 1).

Table 4: ROC curve for obese group in the following parameters

\begin{tabular}{lllllll}
\hline Parameters & AUC & Cut-off value & Sensitivity $\%$ & Specificity & p-value & $95 \% \mathrm{Cl}$
\end{tabular} \begin{tabular}{lcccccc}
\multicolumn{7}{c}{$\%$} \\
\hline Cystatin & 0.506 & 1.525 & 47.2 & 63.9 & 0.928 & $0.371-0.642$ \\
\hline ROC: Receiver operating characteristic. & & & &
\end{tabular}

\section{Discussion}

Obesity is known as a risk factor for the progression of kidney disease. It may also increase mortality risk among children with end-stage renal disease (ESRD). Later in life, healthy overweight and obese children have a higher risk of all-cause ESRD [9]. Thus early evaluation of renal function in obese children is highly important. So, this study was conducted on obese children aged between 10 and 18-years-old to study kidney condition among them and to detect the reliable biomarker for early kidney assessment.

The results showed that serum $\mathrm{Cr}$ was significantly higher in obese participants compared to control besides significant lower e GFR based on $\mathrm{Cr}$. Salman et al., also reported significant lower cr-based eGFR in obese children compared to controls [10]. Correia-Costa et al., evaluated 150 overweight/obese children and showed that overweight/obese children had lower eGFR compared to controls, using numerous formulae [3]. Miliku et al., reported that both eGFR-Cr and eGFR-cystC can be influenced by BMI and body surface area with more influence of eGFR-Cr by body composition [11]. Furthermore, the study of Cindik et al.,

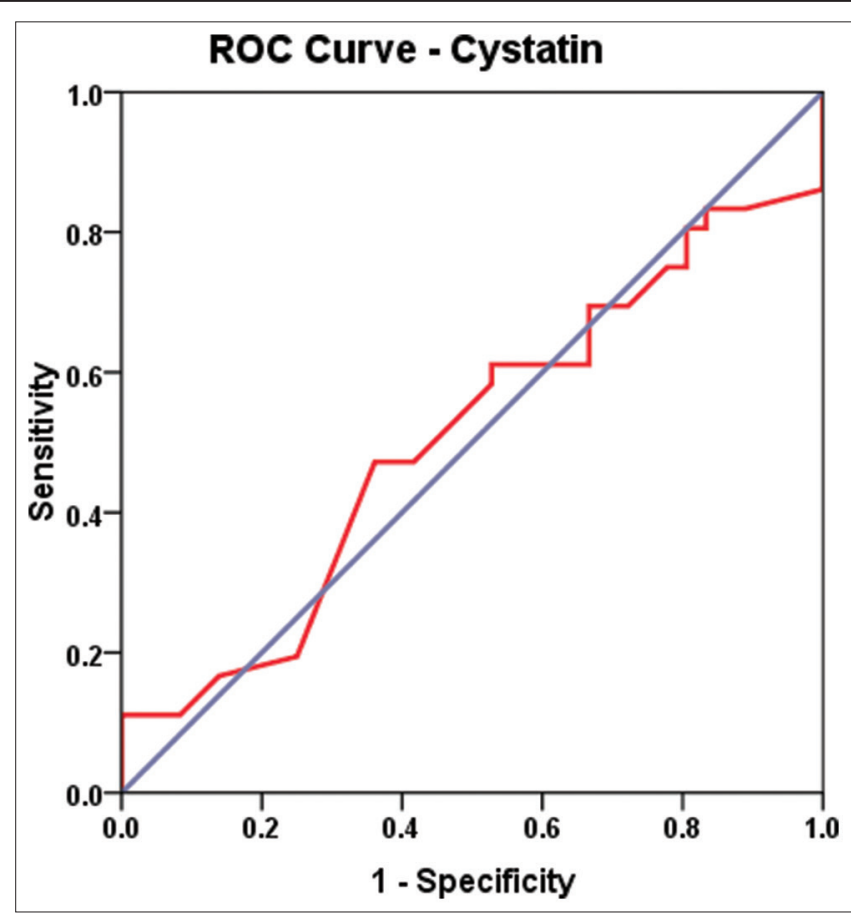

Figure 1: ROC curve for obese group regarding cystatin level. ROC: Receiver operating characteristic

on children aged 7-16.5 years; showed a significant positive correlation between GFR and BMI [12].

For CystC, the current study showed nonsignificant elevation in obese group compared to control. Salman et al., similarly detect non-significant difference between obese children and control besides significant higher mean CystC levels in obese group with metabolic syndrome compared to non- metabolic syndrome group [10]. Actually, Muntner et al., and Shankar et al., reported a graded association between higher BMI and higher CystC in adults, this may explain the importance of WT and BMI monitoring in obese children and adolescence to avoid its dangerous sequels in adulthood life [13], [14]. El-Shaheed et al., conclude that physical activity was encountered in obese adolescence than non-obese one through a WHO validated questionnaire and recommends to raise the awareness and importance to enhance physical activity in obese adolescence to avoid its future complications [15].

Another research found that the most powerful influencers on eating behaviors in adolescence are media, friends and family. Thus, good parental support and understanding have a major imprint on reforming such harmful effect of faulty eating habits. Also, scholastic and college healthy eating programs are extremely important as a source of easy access to widespread information, in order to reduce risk of obesity in this age group [16]. In the current study, the sensitivity and specificity of cystatin for the detection of kidney affection in obese children was $47.2 \%$ and $63.9 \%$ respectively. Higher sensitivity (81\%) and specificity $(88 \%)$ for CystC compared to $\mathrm{Cr}$ for estimating renal function in children and adults was reported in the meta-analysis of Roos 
et al. [17]. Hojs et al., also reported that CystC-based eGFR equation is more sensitive, specific and accurate in overweight and obese persons compared to that of Cr-based eGFR [18]. In the study of Narvaez-Sanchez et al., diagnostic accuracy of CystC and $\mathrm{Cr}$ for estimating GFR was calculated in children with suspected or definite renal insufficiency and aged $<18$ years. Their results showed CystC sensitivity $75 \%$, specificity $84 \%$, and SCr sensitivity $46 \%$, specificity $100 \%$ by using a cut-off value of GFR at $90 \mathrm{~mL} / \mathrm{min}$. They concluded that CystC can replace serum $\mathrm{Cr}$ for evaluating and monitoring kidney function in children [19].

Finally and from the above results, it is now obvious that obesity can unfavorably affect kidney function. Early and precise evaluation can be assessed by $\mathrm{Cr}$ and GFR as a sensitive biomarker for kidney affection in obese children. However, this study has some limitations including small sample size and incomplete evaluation of renal function by other parameters. So in the future, the research on a comprehensive follow-up study will express the importance of Cystatin in the follow-up of obese children and adolescence together with relation to BMI.

\section{Conclusion}

GFR is affected in obese children. Elevated serum $\mathrm{Cr}$ andfollow-up of serum CystC will be needed in obese children and adolescence Thus, $\mathrm{Cr}$ used as a marker for kidney affection in obese children.

\section{Acknowledgment}

The authors are grateful to National Research Center for fund, the administrators, the laboratory team and the nurses of the Medical Research Centre of Excellence (MRCE). Also we express our appreciation to all the children who participated in the study and their parents.

\section{References}

1. Bhadoria A, Sahoo K, Sahoo B, Choudhury A, Sufi N, Kumar R. Childhood obesity: Causes and consequences. J Fam Med Prim Care. 2015;4(2):187-92. https://doi. org/10.4103/2249-4863.154628 PMid:25949965

2. Kovesdy CP, Furth SL, Zoccali C. Obesity and kidney disease: Hidden consequences of the epidemic. Indian J Nephrol. 2017;
27(2): 85-92. https://doi.org/10.1177/2054358117698669 PMid:28540059

3. Salman DÖ, Şıklar Z, İlarslan EN, Özçakar ZB, Kocaay P, Berberoğlu M. Evaluation of renal function in Obese children and adolescents using serum cystatin $C$ levels, estimated glomerular filtration rate formulae and proteinuria: Which is most useful? J Clin Res Pediatr Endocrinol. 2019;11(1):46-54. https:// doi.org/10.4274/jcrpe.galenos.2018.2018.0046 PMid:30145854

4. Ali A, Elkhashab S. Cystatin: Assessment of renal function in chronic kidney disease and postrenal transplant patients. J Egypt Soc Nephrol Transplant. 2019;19:75. https://doi. org/10.4103/jesnt.jesnt_22_18

5. Murty MS, Sharma UK, Pandey VB, Kankare SB. Serum cystatin $\mathrm{C}$ as a marker of renal function in detection of early acute kidney injury. Indian J Nephrol. 2013;23(3):180-3. https:// doi.org/10.4103/0971-4065.111840

PMid:23814415

6. Grubb A. Cystatin $C$ is indispensable for evaluation of kidney disease. EJIFCC. 2017;28(4):268-76. PMid:29333146

7. World Medical Association. Declaration of Helsinki; 2008. Available from: https://www.wma.net/wp-content/uploads/2018/07/doh oct2008.pdf [Last accessed on 2020 Dec 18].

8. Dietians of Canada. WHO Growth Charts for Canada, March 2014 Revision; 2014. Available from: https://www.dietitians.ca/ dietitians-views/prenatal-and-infant/who-growth-charts.aspx. [Last accessed on 2014 Mar ???]

9. Correia-Costa L, Azevedo A, Afonso AC. Childhood obesity and impact on the kidney. Nephron. 2019;143(1):8-11. https://doi. org/10.1159/000492826

PMid:30359981

10. Correia-Costa L, Afonso AC, Schaefer F, Guimarães JT, Bustorff M, Guerra A, et al. Decreased renal function in overweight and obese prepubertal children. Pediatr Res. 2015;78(4):436-44. https://doi.org/10.1038/pr.2015.130 PMid:26151492

11. Miliku K, Bakker H, Dorresteijn EM, Cransberg K, Franco OH, Felix JF, et al. Childhood estimates of glomerular filtration rate based on creatinine and cystatin C: Importance of body composition. Am J Nephrol. 2017;45(4):320-6. https://doi. org/10.1159/000463395 PMid:28245441

12. Cindik N, Baskin E, Agras PI, Kinik ST, Turan M, Saatci U. Effect of obesity on inflammatory markers and renal functions. Acta Paediatr. 2007;94(12):1732-7. https://doi. org/10.1111/j.1651-2227.2005.tb01845

PMid:16421032

13. Muntner P, Winston J, Uribarri J, Mann D, Fox CS. Overweight, obesity, and elevated serum cystatin $\mathrm{C}$ levels in adults in the United States. Am J Med 2008;121(4):341-8. https://doi. org/10.1016/j.amjmed.2008.01.003

PMid:18374694

14. Shankar A, Teppala S. Relationship between body mass index and high cystatin levels among US adults. J Clin Hypertens. 2011;13(12):925-30. https://doi.org/10.111 $1 / \mathrm{j} .1751-7176.2011 .00548$ PMid:22142352

15. Abd El-Shaheed A, Mahfouz NN, Elabd MA, Sallam SF. Physical activity patterns in Egyptian obese and non obese adolescents assessed using a validated WHO questionnaire. J Arab Soc Med Res. 2021;15:6-10. https://doi.org/10.4103/ jasmr.jasmr_27_19

16. El-Shaheed AA, Mahfouz NN, Moustafa RSI, Elabd MA Alarming eating behaviours among adolescents in Egypt. Open 
Access Maced J Med Sci. 2019;7(13):2189-93. https://doi. org/10.3889/oamjms.2019.583

\section{PMid:31456850}

17. Roos JF, Doust J, Tett SE, Kirkpatrick CM. Diagnostic accuracy of cystatin $\mathrm{C}$ compared to serum creatinine for the estimation of renal dysfunction in adults and children-a meta-analysis. Clin Biochem. 2007;40(5-6):383-91. https://doi.org/10.1016/j. clinbiochem.2006.10.026

PMid: 17316593

18. Hojs R, Bevc S, Ekart R, Gorenjak M, Puklavec L. Kidney function estimating equations in patients with chronic kidney disease. Int J Clin Pract. 2011;65(4):458-464. https://doi.org/10. $1111 / \mathrm{j} .1742-1241.2010 .02597$

PMid:21401834

19. Narvaez-Sanchez R, Gonzalez L, Salamanca A, Silva M, Rios D, Arevalo $S$, et al. Cystatin $C$ could be a replacement to serum creatinine for diagnosing and monitoring kidney function in children. Clin Biochem. 2008;41(7-8):498-503. https://doi. org/10.1016/j.clinbiochem.2008.01.022

PMid:18280806

Author Query???

AQ1: Kindly provide last accessed date 